\title{
Biological Value of Protein of Quick-Frozen Semi-finished Products from Cultivated Champignons
}

\author{
Natalia Nesterenko ${ }^{1,}$, , Natalia Orlova ${ }^{1}$, Svitlana Belinska ${ }^{1}$, Iuliia Motuzka ${ }^{1}$, Anastasiya Ivanyuta $^{2}$, \\ Alina Menchynska ${ }^{2}$ \\ ${ }^{1}$ Department of Commodity Science, Safety and Quality Management, Faculty of Trade and Marketing, Kyiv National University of Trade \\ and Economics, Kyiv, Ukraine \\ ${ }^{2}$ Department of Technology of Meat, Fish and Seafood, Faculty of Food Technology and Quality Control of Agricultural Products, National \\ University of Life and Environmental Sciences of Ukraine, Kyiv, Ukraine
}

\section{Email address:}

Natysik88@bigmir.net (N. Nesterenko), belinskas@ukr.net (S. Belinska),unmot@ukr.net (I. Motuzka), nastasushka@bigmir.net (A. Ivanyuta), menchynska@ukr.net (A. Menchynska)

*Corresponding author

\section{To cite this article:}

Natalia Nesterenko, Natalia Orlova, Svitlana Belinska, Iuliia Motuzka, Anastasiya Ivanyuta, Alina Menchynska. Biological Value of Protein of Quick-Frozen Semi-finished Products from Cultivated Champignons. International Journal of Food Science and Biotechnology.

Vol. 5, No. 4, 2020, pp. 79-83. doi: 10.11648/j.ijfsb.20200504.17

Received: November 17, 2020; Accepted: November 27, 2020; Published: December 4, 2020

\begin{abstract}
Biological value of protein of quick-frozen semi-finished products from cultivated champignons has been studied. Results of the study of total, protein and non-protein nitrogen in semi-finished products with mushrooms before the freezing and during the low-temperature storage are presented in this work. High preservation of protein after 12 months of low-temperature storage in experimental samples of semi-finished products in comparison with control samples has been established. The amino acid composition of semi-finished products has been determined by the method of ion-exchange column liquid chromatography using an automatic amino acid analyzer. Biological value of protein of quick-frozen semi-finished products from cultivated champignon has been determined by the amino acid composition of the experimental sample in comparison with the amino acid composition of the reference protein, proposed by FAO / WHO, and the following calculation of the amino acid score. Studies have shown that the dominant amino acids in all samples are tryptophan, phenylalanine and tyrosine. The main limiting amino acids are methionine and cystine. Studies of nitrogenous commercial mushroom semi-finished products have shown that quick-frozen semi-finished products from cultivated mushrooms, which have been pre-treated, regardless of the mushrooms varieties, have a higher biological value compared to the control samples.
\end{abstract}

Keywords: Cultivated Champignons, Total, Protein Nitrogen, Non-protein Nitrogen, Amino Acid Composition

\section{Introduction}

Biological value of food is determined by the qualitative composition of the protein, which reflects the degree of compliance of its amino acid composition with the body's needs in amino acids, which are necessary for protein synthesis processes. Today, about 80 countries around the world cultivate champignon, oyster mushroom, shiitake, honey fungus, winter mushroom, Stropharia and other mushrooms. According to scientists, $2 / 3$ of human protein needs will be met through industrial production of cultivated mushrooms in the future $[1,2]$. Nitrogen substances, which are in the form of protein (up to $70 \%$ of their total amount) and intermediates of protein metabolism (amines, ammonia, urea, free amino acids, etc.) are the most important component of the dry weight of the fruiting body of cultivated mushrooms [3]. Analysis of literature revealed that the digestibility of fungal protein is in the range of $54-85 \%$ (average $70 \%$ ), vegetable one $-61.6-72 \%$ (average $68 \%$ ), animal protein - 95-98\% (average 96.5\%) [4, 5]. Researches by scientists [6] have shown that 19 amino acids were found and identified in mushroom proteins; almost $41 \%$ of them are 
appeared to be essential amino acids. However, fungi are "living" organisms, and biochemical processes are still ongoing, even during the storage period, first of all breathing and enzymatic hydrolytic processes, they mature quickly, the appearance deteriorates, tissue turgor is lost. As a result of deep hydrolytic processes, the amount of protein and polysaccharides decreases, and the nutritional value of mushrooms decreases. Due to the low viability of fresh mushrooms, product losses in the process of trade are about $47 \%[7,8]$. In order to produce waste-free mushrooms and expand the range of mushroom products as ready for consumption as possible, we have developed quick-frozen semi-finished products from cultivated mushrooms, which have been pre-treated with polysaccharides of natural origin [9].

The aim of the work is to study the change in the content of nitrogenous substances and amino acid composition of quick-frozen semi-finished products from cultivated mushrooms in the process of freezing and low-temperature storage.

The objects of the study were:

Quick-frozen semi-finished products from cultivated white and brown champignon varieties - Hauser A-15 and № 117 strains, respectively, with a closed cap; which were subjected to preliminary blanching and treated with polysaccharides of natural origin (Experiment);

Quick-frozen semi-finished products from cultivated white and brown champignon varieties - Hauser A-15 and № 117 strains, respectively, with a closed cap, without blanching and without the use of natural thickeners (Control).

\section{Materials and Methods}

The essence of the method for the determination of total, protein and non-protein nitrogen by the chloramine method is the combustion of organic matter with sulfuric acid in the presence of a catalyst for copper sulfate to carbon dioxide and water.

Amino acid composition was determined by ion exchange liquid column chromatography using an automatic amino acid analyzer T339. For the separation of amino acids one used fine-grained cation exchangers (resins), which are a copolymer of styrene and divinylbenzene of a spherical shape with a functional group $-\mathrm{SO}_{3}{ }^{-}$.

Amino acid score was calculated by the ratio of the content of amino acid composition of the test protein to a similar indicator of the reference protein according to FAO / WHO.

\subsection{Sample Preparation}

To determine the total protein, one add sodium molybdate, hydrogen peroxide and potassium sulfate to the test sample, followed by burning of the sample in the presence of hydrochloric acid.

To determine the non-protein nitrogen, a test sample is ground in a mortar with distilled water to a homogeneous mass, add a solution of copper sulfate, mix and transfer the homogenate to a centrifuge tube, precipitate the proteins with copper hydroxide, separate by centrifugation and wash with distilled water. The solution containing non-protein nitrogen is transferred to Kjeldahl Flask, evaporated, followed by combustion with sulfuric acid and determination of nitrogen by chloramine method [10].

Preparation of samples determining the amino acids content is: to add to the sample of the test sample, which was previously placed in a test tube with a ground tube of distilled water and concentrated hydrochloric acid, followed by drying. The next step was to filter and wash hydrolyzate obtained with a distilled water, followed by its transfer to a porcelain cup and evaporation on an electric stove. The resulting sample is diluted with a distilled water, filtered and the amino acid content can now be determined. Ion-exchange column chromatography is based on acid-base properties of amino acids. To quantify the amino acids in the test sample, a standard mixture of amino acids with a known concentration of each amino acid is applied to the column of the automatic amino acid analyzer and the peak area of each amino acid is calculated on the chromatogram. Tryptophan during the acid hydrolysis of protein is almost completely decomposed, so a separate analysis for its determination has been performed using alkaline hydrolysis $[11,12]$.

\subsection{Calculation of Total, Protein and Non-protein Nitrogen}

Total protein content was calculated by formula (1):

$$
\mathrm{X}=0,4669 * \mathrm{~K}^{*} \mathrm{~A} *(\mathrm{a}-\mathrm{b}) / \mathrm{V}^{*} \mathrm{n},
$$

where $\mathrm{X}$ is the nitrogen content in terms of absolute dry substance (in \%); $\mathrm{A}$ - the volume of solution in which the sample is dissolved after combustion (in $\mathrm{ml}$ ); $\mathrm{K}$ - the normality of the sodium thiosulfate solution, $\mathrm{V}-$ the volume of the test solution taken for nitrogen oxidation by chloramine (in $\mathrm{ml}$ ); a - volume of 0.02 sodium thiosulfate solution spent for the titration of the control solution (in $\mathrm{ml}$ ); $\mathrm{b}$-volume of 0.02 sodium thiosulfate solution spent for the titration of the test solution (in $\mathrm{ml}$ ); $\mathrm{n}$ - absolute - dry sample (in terms of absolute dry substance, that is necessary to determine the mass fraction of moisture of the test sample), g; 0.4669 - normal nitrogen titer multiplied by 100 for conversion into percent.

Calculations of non-protein nitrogen was carried out according to the formula:

$$
\mathrm{X}=0,4669 * 50 * \mathrm{~K} *(\mathrm{a}-\mathrm{b}) / 25 * \mathrm{n},
$$

where $\mathrm{X}$ - the content of non-protein nitrogen (in \%); 50 the volume of test solution (in $\mathrm{ml}$ ); 25 - the volume of the test solution taken to determine nitrogen by the chloramine method (in $\mathrm{ml}$ ); a - volume of 0.02 sodium thiosulfate solution spent on titration of the control solution (in $\mathrm{ml}$ ); $\mathrm{b}$ volume of 0.02 sodium thiosulfate solution spent on titration of the test solution (in $\mathrm{ml}$ ); $\mathrm{K}$ - standard of the sodium thiosulfate solution; $\mathrm{n}$ - the sample of the test sample (in $\mathrm{g}$ ).

Calculation of protein nitrogen was calculated by the formula: 


$$
\mathrm{X}=0,4669 * 50 * \mathrm{~K} *(\mathrm{a}-\mathrm{b}) / 10 * \mathrm{n},
$$

where $\mathrm{X}$ is the content of protein nitrogen (in \%).

The number of micromoles of each amino acid in test sample was calculated by the formula:

$$
\mathrm{X}=\mathrm{S}_{1} / \mathrm{S}_{0},
$$

where $\mathrm{X}$ - micromoles of each amino acid; $\mathrm{S}_{1}$ - the area of the amino acid peak in the test sample; $\mathrm{S}_{0}$ - the peak area of the same amino acid in a solution of a standard mixture of amino acids, corresponding to 1 micromolar amount of each amino acid. The amount in milligrams was calculated by the multiplying of the number of micromoles of amino acid with the corresponding molar mass.

Calculation of the amino acid score of each essential amino acid was calculated by the formula:

$$
\mathrm{C}_{\mathrm{j}}=\mathrm{AK}_{\mathrm{i}} / \mathrm{AK}_{\mathrm{i}}^{\text {etal }} * 100,
$$

where $\mathrm{C}_{\mathrm{j}}$ - amino acid score of the essential amino acid of the protein, $\% ; \mathrm{AK}_{\mathrm{i}}$ - the content of essential amino acid protein, $\mathrm{g} / 100 \mathrm{~g}$ of protein of the test sample; $\mathrm{AK}_{\mathrm{i}}{ }^{\text {etal }}$ - the content of essential amino acid in the reference protein, $\mathrm{g} / 100 \mathrm{~g}$ of the reference protein.

\section{Results and Discussion}

The results of studies of the content of nitrogenous substances in quick-frozen semi-finished products from cultivated mushrooms of white and brown varieties are given in Table 1. According to the results of the research, it has been found that the mass fraction of total nitrogen in quick-frozen semi-finished products from cultivated mushrooms for both, white and brown varieties, after the freezing, decreases in comparison with the samples of semi-finished products before the freezing. The mass fraction of protein nitrogen in frozen champignons of all varieties significantly exceeds the proportion of non-protein nitrogen. When converting protein nitrogen to protein (absolute dry weight), it has been found that most of its preservation after 12 months of low-temperature storage is observed in the experimental samples of semi-finished products, much lower content has been found in control samples.

This is probably due to the increased moisture retention capacity of protein colloids of fungal tissue [13], which indicates the stability of their structure after thawing.

\begin{tabular}{|c|c|c|c|c|c|c|c|c|}
\hline \multirow{3}{*}{ Research stage } & \multicolumn{6}{|c|}{ Nitrogen content, $\%$ of absolute dry weight } & \multirow{2}{*}{\multicolumn{2}{|c|}{ Total protein content }} \\
\hline & \multicolumn{2}{|c|}{ Total } & \multicolumn{2}{|l|}{ Protein } & \multicolumn{2}{|c|}{ Non-protein } & & \\
\hline & Control & Test & Control & Test & Control & Test & Control & Test \\
\hline Before freezing & 7,11 & 7,12 & $5,52 \pm 0,27$ & $5,53 \pm 0,27$ & $1,59 \pm 0,07$ & $1,59 \pm 0,07$ & 34,50 & 34,56 \\
\hline 1 month of storage & 6,20 & 7,05 & $5,19 \pm 0,26$ & $5,45 \pm 0,27$ & $1,01 \pm 0,05$ & $1,6 \pm 0,08$ & 32,43 & 34,06 \\
\hline 3 months of storage & 6,05 & 7,03 & $5,07 \pm 0,25$ & $5,31 \pm 0,26$ & $0,98 \pm 0,04$ & $1,72 \pm 0,086$ & 31,68 & 33,18 \\
\hline 9 months of storage & 5,35 & 6,95 & $4,08 \pm 0,20$ & $5,17 \pm 0,25$ & $1,27 \pm 0,63$ & $1,78 \pm 0,089$ & 25,50 & 32,31 \\
\hline 12 months of storage & 5,13 & 6,93 & $3,90 \pm 0,19$ & $5,03 \pm 0,25$ & $1,23 \pm 0,61$ & $1,90 \pm 0,09$ & 24,37 & 31,43 \\
\hline \multicolumn{9}{|c|}{ Quick-frozen semi-finished product from brown champignons of strain № 117} \\
\hline Before freezing & 7,32 & 7,32 & $5,77 \pm 0,28$ & $5,77 \pm 0,28$ & $1,55 \pm 0,07$ & $1,55 \pm 0,077$ & 36,06 & 36,06 \\
\hline 1 month of storage & 6,40 & 7,25 & $5,40 \pm 0,27$ & $5,67 \pm 0,28$ & $1,0 \pm 0,05$ & $1,58 \pm 0,079$ & 33,75 & 35,43 \\
\hline 3 months of storage & 6,25 & 7,23 & $5,32 \pm 0,26$ & $5,52 \pm 0,27$ & $0,93 \pm 0,04$ & $1,71 \pm 0,085$ & 33,25 & 34,50 \\
\hline 9 months of storage & 5,67 & 7,15 & $4,51 \pm 0,22$ & $5,31 \pm 0,26$ & $1,16 \pm 0,05$ & $1,84 \pm 0,092$ & 28,18 & 33,18 \\
\hline 12 months of storage & 5,54 & 7,10 & $4,05 \pm 0,20$ & $5,27 \pm 0,26$ & $1,49 \pm 0,07$ & $1,83 \pm 0,091$ & 25,31 & 32,93 \\
\hline
\end{tabular}

Table 1. Change in the content of nitrogenous substances in quick-frozen semi-finished products from cultivated mushrooms in the process of freezing and low-temperature storage, $\%$.

One of the most important indicators of the nutritional value of mushroom semi-finished products is the balance of their amino acid composition, namely, the content and quantitative ratio of essential amino acids (Table 2).

According to the results of experimental studies, it has been found that 18 amino acids were identified in the proteins of quick-frozen semi-finished products from cultivated mushrooms, regardless of the strain of the fungi. It has been determined that mushrooms semi-finished products of both white and brown varieties are characterized by the presence of all essential amino acids; the dominant ones were leucine and lysine.

Leucine is one of the essential amino acids that is not synthesized by the body's cells, so it enters the body exclusively as a part of natural food proteins, is a major component of all natural proteins, is actively involved in protein synthesis and breakdown. The absence or lack of leucine in the body can lead to metabolic disorders, stunted growth and development, weight loss [14].

Lysine is necessary for normal bone formation and growth in children bodies, promotes calcium absorption and normal nitrogen metabolism for adults, is a building material of blood cells; it strengthens the circulatory system and supports normal cell growth, participates in the synthesis of antibodies, hormones, enzymes, collagen formation and tissue repair, lowers serum triglycerides [15].

Among the substituted amino acids in terms of quantitative content, glutamic and aspartic acids are predominant, which 
coincides with the data of literature sources [16].

Table 2. Amino acid composition of quick-frozen semi-finished products from cultivated champignons after 12 months of low-temperature storage, $g / 100 \mathrm{~g}$ of protein.

\begin{tabular}{lllll}
\hline Amino acid & \multicolumn{4}{l}{ Quick-frozen semi-finished products from champignons } \\
\hline & white champignons of the Hauser A-15 strain & brown champignons of strain № 117 & Test \\
\cline { 2 - 5 } & Control & Test & Control & 3,4 \\
\hline Valine & 2,8 & 3,0 & 3,1 & 3,4 \\
Isoleucine & 2,73 & 3,2 & 2,9 & 5,5 \\
Leucine & 5,0 & 5,2 & 5,3 & 4,55 \\
Lysine & 4,05 & 4,4 & 4,5 & 0,75 \\
Methionine & 0,60 & 0,69 & 0,66 & 3,3 \\
Threonine & 2,8 & 2,9 & 1,3 \\
Tryptophan & 1,0 & 1,3 & 1,3 & 3,3 \\
Phenylalanine & 3,3 & 3,1 & 25,5 \\
The amount of essential amino acids & 22,28 & 3,5 & 3,66 \\
Arginine & 2,4 & 24,19 & 23,46 & 7,2 \\
Aspartic acid & 6,0 & 3,32 & 2,9 & 5,54 \\
Histidine & 4,45 & 6,79 & 6,5 & 3,9 \\
Glycine & 3,96 & 4,97 & 13,76 \\
Glutamic acid & 9,97 & 3,25 & 3,1 \\
Proline & 4,49 & 4,02 & 12,54 & 3,9 \\
Serine & 2,6 & 11,66 & 2,5 & 2,15 \\
Tyrosine & 1,7 & 5,16 & 3,0 & 1,43 \\
Cystine & 1,23 & 3,31 & 1,98 & 6,0 \\
Alanine & 5,6 & 1,91 & 1,28 & 50,64 \\
The amount of substituted amino acids & 42,4 & 1,4 & 54,72 & \\
\hline
\end{tabular}

Glutamic acid plays a major role in a nitrogen metabolism, participates in a protein and carbohydrate metabolism, stimulates oxidative processes, prevents a decrease in redox potential, increases the body's resistance to hypoxia, normalizes metabolism. Aspartic acid plays an important role in the proper functioning of the immune, nervous and endocrine systems, is involved in the synthesis of immunoglobulins $[17,18]$.

Serine and arginine amino acids are hydrophilic amino acids that determine the moisture-retaining ability of mushrooms semi-finished products.

According to the results of studies (Table 2), the proteins of the control samples semi-finished products from cultivated mushrooms contain an even smaller number of these amino acids compared to the experimental ones, which allows us to judge the relatively high moisture-retaining ability of the latter.

According to the scientifically substantiated concept of complete nutrition, the biological value of products is determined not only by the presence and mass fraction of individual amino acids, but mainly by their balance, which is the main condition for human existence, because the human body gets everything it needs with food to build cells and tissues of the body, as well as replenishes energy expenditure for all activities. Therefore, foods should contain biologically active substances in the optimal quantitative and qualitative ratio.

Biological value of a protein in terms of amino acid composition can be assessed by comparing it with the amino acid composition of the reference protein proposed by FAO / WHO and the following calculation of the amino acid score (Table 3).

According to the results of the calculation of the amino acid score, it has been found that semi-finished products from cultivated champignons of both white and brown varieties contain the whole complex of essential amino acids. Table 3 shows that the dominant amino acids in all samples are tryptophan, phenylalanine and tyrosine. The main limiting amino acids are methionine and cysteine ones.

Table 3. Amino acid score of quick-frozen semi-finished products from cultivated champignons after 12 months of low-temperature storage, (compared to the FAO / WHO scale), \%.

\begin{tabular}{|c|c|c|c|c|}
\hline \multirow[t]{3}{*}{ Amino acid } & \multicolumn{4}{|c|}{ Quick-frozen semi-finished product from champignons } \\
\hline & \multicolumn{2}{|c|}{ white champignons of the Hauser A-15 strain } & \multicolumn{2}{|c|}{ brown champignons of strain № 117} \\
\hline & Control & Test & Control & Test \\
\hline Isoleucine & 68,25 & 80,00 & 72,50 & 85,00 \\
\hline Leucine & 71,43 & 74,29 & 75,71 & 78,57 \\
\hline Lysine & 73,64 & 80,00 & 81,82 & 82,73 \\
\hline Threonine & 70,00 & 72,50 & 70,00 & 82,50 \\
\hline Tryptophan & 100,00 & 130,00 & 110,00 & 130,00 \\
\hline Phenylalanine + tyrosine & 83,33 & 90,17 & 84,67 & 90,83 \\
\hline
\end{tabular}




\section{Conclusions}

Studies of nitrogenous substances in mushrooms semi-finished products have concluded that quick-frozen semi-finished from cultivated champignons, which have been pre-treated, regardless of the variety or strain of mushrooms, have a higher biological value compared to the control. In our opinion, such results are related to the ability of polysaccharides of natural origin to retain moisture, and thus strengthen the hydrogen bonds between protein and water molecules. As a result, more protein macromolecules are stored in the native state. There is a decrease in the amount of nitrogenous substances in control samples. This is due to the destruction of the crystal lattice system of water particles around the hydrophobic groups of proteins after the freezing. Breaking of these hydrogen bonds causes the loss of the native properties of protein substances. During the denaturation processes, the secondary and tertiary structure of proteins is destroyed, and as a result - they are attacked by proteolytic enzymes and undergo hydrolytic decomposition with the formation of simpler compounds.

\section{References}

[1] Dyatlov V. V., Popova N. A., Medvedkova I. I. (2011). Quality and harmlessness of champignons during the storage [Kachestvo i bezvrednost' shampin'onov pri khranenii]. Tovaroznavchyi visnyk, 3: 95-103.

[2] Simakhina H. O., Hoyko I. M., Stetsenko N. A. (2014). Processing of edible mushrooms to obtain protein-containing semi-finished products [Pererobka yistivnykh hrybiv dlya otrymannya bilokvmisnykh napivfabrykativ]. Goods and markets, №2: 70-79.

[3] Bakaitis V. I. (2006). Theoretical and experimental substantiation of increase of consumer properties and preservation of mushroom production [Teoreticheskoye i eksperimental'noye obosnovaniye povysheniya potrebitel'skikh svoystv i sokhranyayemosti gribnoy produktsii]. Kemerovo.

[4] Tsapalova I. E., Bakaitis V. I., Kutafieva N. P. (2002). Examination of mushrooms [Ekspertiza gribov]. Novosibirsk: Novosibirsk Publishing House.

[5] Pavlyuk R. YU., V. V. Poharska, L. O. Radchenko, R. D. Tauber, T. S. Matsipura, O. A. Kaplun (2017). Development of a new generation of health nanoproducts from champignon mushrooms for restaurant business enterprises [Rozrobka novoho pokolinnya ozdorovchykh nanoproduktiv iz hrybiv shampin'oniv dlya pidpryyemstv restorannoho biznesu]. Scientific journal Science Rice, №5 (34): 38-44.

[6] Connell J. E., Esselen W. B. (1997). Carbohidrates in cultivated mushrooms. Food, Vol. 5 (12): 118-121.
[7] Nesterenko N. A. (2011). Production and consumption of cultivated mushrooms in Ukraine [Virobnitstvo i spozhivannya kul'tivovanikh gribov v Ukraine]. Goods and markets, 2 (12): 61-68.

[8] Orlova N. Ya., Nesterenko N. A. (2012). Freezing as an effective way to preserve the original consumer properties of cultivated champignons [Zamorozhuvannya - yefektivniy sposíb zberezhennya vikhídnikh spozhivnikh vlastivostey kul'tivovanikh pecherits']. In: Actual problems of development of food production, restaurant and hotel facilities and trade: thesis for All-Ukrainian scientific-practical conference of young scientists and students, April 25. Kharkiv: KhDUHT, p. 81 .

[9] Orlova N. Ya., Nesterenko N. A. (2012). Consumer properties of frozen mushrooms depending on pre-treatment procedure [Spozhivní vlastivostí zamorozhenikh pecherits' zalezhno víd poperedn'oí obrobki]. Food industry of agro-industrial complex, 2: 41-43.

[10] Pochinok Kh. N. (1976). Methods of biochemical analysis of plants [Metody biokhimicheskogo analiza rasteniy]. Naukova dymka.

[11] Ovchinnikova Yu. A. (1974). New methods for the analysis of amino acids, peptides and proteins [Novyye metody analiza aminokislot, peptidov, belkov]. Moscow: «Mir».

[12] Kozachenko T. D. (1975). Ion exchange chromatography of amino acids. Novosibirsk [Ionoobmennaya khromatografiya aminokislot]. Novosibirsk: «Nauka».

[13] Orlova N. Ya., Nesterenko N. A., Kameneva N. V. (2012). Quality optimization of quick-frozen semi-finished products from cultivated champignons [Optimizatsiya yakostí shvidkozamorozhenikh napívfabrikatív íz kul'tivovanikh pecherits']. Goods and markets, №1 (13): 64-71.

[14] Leucine as the most important amino acid [Leytsin - samaya glavnaya aminokislota]. [Online]. Available at: https://sportivnoepitanie.ru/biblioteka.aspx?a=aminokislotalejcin.

[15] Pharmacological Encyclopedia. Lysine [Farmakologíchna yentsiklopedíya. Lizin]. [Online]. Available at: https://www.pharmencyclopedia.com.ua/article/2067/lizin.

[16] Hnitsevych V. A., Chekhova N. S. (2017) Scientific substantiation of the use of mushroom powder in the technology of culinary products [Naukove obhruntuvannya vykorystannya hrybnoho poroshku u tekhnolohiyi kulinarnykh vyrobiv]. Modern food technologies, №34: 5-10.

[17] Aspartic acid: effects on the body [Asparagínova kislota: vpliv na organízm]. [Online]. Available at: https://medfond.com/ korysni-produkty/korist- asparaginovoi-kisloti.html.

[18] Chemistry online. Aspartic acid. [Khimiya onlayn. Asparaginovaya kislota]. [Online]. Available at: https://himija-online.ru/organicheskaya-ximiya/aminokisloty/a sparaginovaya-kislota.html. 